\title{
Partisanship and Electoral Reform: Change in Congressional Cohesion, 1877-1932
}

\author{
by \\ Rick K. Wilson \\ Rice University \\ National Science Foundation
}

Thanks are due to Brian Posler and Allison Rinden, both of whom did some of the grunt work associated with assembling the data used in this paper. The National Science Foundation is not reponsible for any of the conclusions reached in this research. Paper prepared for the Annual Meeting of the American Political Science Associaton, Washington, D.C., August 28-31, 1997. 


\begin{abstract}
Explanations for the decline of partisanship in the early part of the 20th century are at odds. The received wisdom holds that a set of electoral reforms led Congressmen to break their partisan ties, engaging in more familiar modes of personalistic behavior. This view has recently been challenged noting that the bulk of the reforms passed in the Populist and Progressive periods eliminated factional strife within parties and led to increased partisanship. This paper looks at a wide variety of reforms introduced in a 40 year period. While a set of early ballot reforms did result in increased levels of state delegation partisanship, subsequent reforms, combined with the passage of time, undermined partisan strength in the U.S. House of Representatives.
\end{abstract}




\section{Introduction}

The ebb and flow of party strength remains a puzzle for Political Scientists. This is especially true for partisanship within the U.S. Congress. At the outset of the twentieth century levels of party cohesion were extremely high, but steadily declined in the subsequent two decades. Reaching a low water mark in the 1960s, party cohesion resurged in the 1980s, with measurable levels of party voting approaching that observed in the heyday of "boss rule." These swings in Congress have been well documented (Brady, Cooper and Hurley, 1979; Hurley and Wilson, 1989; Patterson and Caldeira, 1988). While the resurgence in the 1980s has been explained by many (in particular, see Rohde, 1992), our explanations remain incomplete.

Key to understanding partisan strength in the U.S. Congress is explaining the precipitous decline of partisanship at the turn of this century. Numerous explanations have been offered, and one which has gained widespread currency points to fundamental changes in electoral rules. In particular, ballot reform rules that were adopted to overcome local party factionalism in the 1890's and Progressive reforms designed to both expand and constrict electoral participation, were thought to undermine partisan linkages between the electorate and those holding office. In turn, it is argued that the electoral linkage was transformed such that office holders became more closely tied to their constituents. The net effect was a slow erosion of party controls over the behavior of office holders.

This paper first details the current explanations for partisan decline around the turn of the 20th century. While there is a standard story focused on the role of rules, recently this view has been challenged (Reynolds, 1995, 1997). In the second section several hypotheses are offered that are derived from these competing approaches. The third section details a set of reforms that dominated the political landscape during the period 1876 to 1932. Finally, a set of models estimate the impact of these reforms on levels of partisanship among Congressional state delegations throughout this period.

\section{Explanations for Partisan Decline in the "Golden Age of Party"}

The dominant explanation for the decline of partisanship at the turn of the twentieth century focuses on changes in the electoral rules pressed by Populists and Progressives. ${ }^{1}$

\footnotetext{
1 This sweeping statement is not intended to shortchange the pioneering work by Cooper, Brady and Hurley (1977), among others, who noted the rise and fall of partisanship in the U.S. House of Representatives over time. Their approach produces a complex explanation that points to large-scale changes occuring in the general political environment as well as within the House. Given the discipline's recent focus on electoral reforms, my focus reflects such concerns.
} 
By changing the "rules of the game" reformers broke down the ability of party bosses to control elections. Weakened partisan bonds meant that elected officials were now more closely attached to constituents, and constituent interests often diverged from purely partisan politics. Consequently elected officials were less likely to toe a party line and observable measures of partisan attachment were likely to decline. A number of studies have shown that changes in electoral rules, whether it be the introduction of the Australian ballot (Rusk, 1970) or the direct primary (Galderisi and Ginsberg, 1986) were correlated with a decline in partisan attachment. Katz and Sala (1996) go so far as to argue that the introduction of the secret ballot transformed the institution of Congress, cementing into place a norm in which re-elected members had a property right claim to committee appointments.

It has been proposed that each change in the rules had an impact on eroding the control of party bosses. As Galderisi and Ginsberg (1986) argue, the direct primary was one of the more interesting of the reforms introduced during the Progressive period.

"The primary can be seen as an antiparty reform on three separate counts. First, by weakening party leaders' capacity to control nominating processes, primary elections undermine the organizational coherence of established parties. Second, primaries tend to direct the attention of voters and political activists toward the nominating contests of the party most likely to win the general election, and away from the interparty race. ... Last, and most interesting, primary elections have the effect of inhibiting the formation of new parties." (p. 116)

The argument for the latter point is that contested primaries allow dissidents to oppose within established parties rather than challenge from the outside. Consequently, attention turns away from building a new third party in order to opt to work from within.

The principal evidence offered for the impact of changing electoral rules has focused on the Australian ballot. The argument typically offered holds that the secret ballot directly removed the ability of partisan bosses to control votes. Prior to the introduction of the secret ballot, parties (or even splinter groups) printed their own ballots which were handed to voters and which could be dropped into a ballot box. Because only one such voting slip could be dropped into the ballot box, this required that someone watch to prevent more than one vote being cast. Obviously, because ballots were distinctive, this also allowed partisan observers to monitor who was for and against them. The Australian ballot, which required that the state or local government print a standard ballot and required voters to mark their ballot, ensured secrecy when casting the ballot and removed partisan monitoring. If a voter was "bought" it was no longer clear whether he stayed that way when casting his vote. 
Recently this view has been challenged. Reynolds (1995) points out that ballot reforms were aimed at curbing abuses created by urban political machines. Rather than behaving as tightly controlled national political parties these local machines were fractionated and factional. Reynolds' claim is that the reformist movements were led by state party leaders who viewed these reforms as an opportunity to retrench the two major parties in the political process. By requiring a centralized, standardized ballot, the major parties could squeeze out third party competition and they could curtail factions within their own party. Indeed, Reynolds provides very strong evidence that the introduction of the Australian ballot and mechanisms for voting via party list led to increased cohesion within the parties -- particularly at the national level (see Reynolds, 1997).

Reynolds may well be correct in arguing that the net effect of populist (and later progressive) reforms strengthened national political parties, rather than undermined them. However, the Australian ballot was only one of many reforms pursued by reformers. As Burnham (1970), among many others, notes the reform movements that gained steam in the cities in the 1890s pressed for a wholesale transformation of the American electoral system. At least two general sets of reforms were sought. The first tried to undermine urban political machines by implementing the Australian Ballot, direct primaries and atlarge, non-partisan elections. The net effect of these major reforms (and a host of minor experiments) was, in Burnham's mind, to erode party functions. In turn, as Rusk (1970) and others claim, this weakened the grip of Congressional partisans in both Chambers.

The second set of reforms, rather than breaking down control by party elites, turned to curbing electoral abuses by citizens. These reforms included allowing women's suffrage, thereby enfranchising a group that was expected to have a leavening effect on the political process, the introduction of poll taxes and other barriers to voting, effectively disenfranchising a different group and lessening competition in the South, and finally by requiring personal registration of voters to limit the amount of fraud due to individuals casting multiple ballots.

Burnham is quite deliberate in his conclusions about the consequences of these reforms. As he argues, it was not one or the other of these reforms that lead to the decline of partisan attachment at the outset of the 20th century. Instead, he notes

"...most if not all of these fundamental changes in the 'rule of the game' were in effect devices of political establishment and control, with strongly conservative latent consequences if not overt justifications, and with an overwhelmingly antipartisan bias." (p. 74). 
Burnham is only echoing the arguments offered by many Progressives at the turn of this century. For example, Ernst Mayer, in a self-published treatise advocating the primary system as a means for wresting control from partisan bosses, argued

"Closely related to the Australian ballot and the primary election reforms safeguarding our nominations and elections, is that which aims to punish the corrupt use of money and other forms of bribery in securing either nominations or elections to office. These reforms are all complementary. Neither one is complete in itself, and all cooperate for a common end, -- the establishment of more perfect institutions for the selection of our public service." (1902, p. 444).

Changing a single rule of the electoral game was not regarded as sufficient. Instead, a galaxy of electoral reforms were necessary in order to return to political order (of course, see Wiebe, 1967 for a trenchant analysis as to whose order was being restored).

Regardless of the reformist claims, perhaps there is truth in the matter that an array of reforms, which were implemented at different times, had an impact on voter's partisan attachments and consequently on the attachments of members to party-in-the-Congress. Certainly Rusk and Stucker (1978) provide strong evidence for at least the first part of this equation in southern states. They analyze the confluence of a large number of electoral reforms and links their impact to Congressional state delegations. Rather than resting with Reynold's conclusions about the impact of the Australian ballot on cohesion among partisans in Congress, I press as to whether the change in the ballot, coupled with a myriad of other reforms, had an impact on shifting levels of cohesion in the U.S. Congress.

\section{Hypotheses}

The principle hypothesis is very straightforward. The cumulative effect of ballot and electoral process reforms was to break down levels of cohesion in state congressional delegations. While several of the ballot reforms in the 1890's may have boosted state party control over the nomination and election of members to the U.S. Congress, over time that control shifted from the party to the individual representatives. With the addition of Progressive reforms that controlled access to the ballot and enhanced the ability of voters to mask their partisan allegiance, representatives increasingly had to tie their fortunes to the voters and were less bound to the dictates of party interests. This meant that where the electoral rules provided new incentives to respond to voters, members of congress did so. All of this occurred at the same time that the tenure for members of congress was increasing. 
Hypothesis 1. The net effect of ballot and electoral reforms was a decline in state delegation partisan attachment.

If the hypothesis is incorrect then the reforms should have no independent effect. Instead, the observed shift in aggregate partisan attachment is due to some other combination of variables. Because these reforms were adopted at different times in different states, the effects of different reforms will be negligible.

Hypothesis 2. The short term effects of ballot reforms was to strengthen state delegation partisan attachment.

Hypothesis 2 extends directly from the discussions by Reynolds (1995, 1997). Her arguments and data point out that fundamental changes in the ballot structure meant increased control by state party leaders and eliminated the factionalism that had often been present in parties. However, these reforms, while eliminating factional strife within the party, also planted the seeds for individual candidates to build their own voting coalitions. If similar findings are not uncovered here, then the measures I use can be called into question.

Hypothesis 3. The short and long term effects of Progressive electoral system reforms was to weaken state delegation partisan attachment.

Hypothesis 3 distinguishes between ballot reforms and electoral reforms. The latter aimed to eliminate electoral fraud and to "cleanse" the pool of eligible voters. This in turn decreased the ability of partisan machines to control who was placed on the ballot and led to a steady decline in partisan attachment.

Fortunately, from the standpoint of a social scientist trying to disentangle these different effects, not all reforms were adopt in all states nor were they adopted at the same time. As a consequence, by taking a lengthy time series and tracing when reforms were differentially implemented, it is possible to tease out the impact of these different reforms and address these different hypotheses.

\section{Data}

The data used for this analysis cover the period 1876 (when members of the 45th Congress were first elected) to 1932 (when members of the 73rd Congress were elected). Two distinct types of data were used. The first constitute measures of partisanship within the U.S. House of Representatives. These are recovered from recorded votes provided by the ICPSR. The second type of data concerns the electoral rules adopted by each state during this period. 
The key dependent variables are derived from measures of party voting in the US Congress. Two types of measures are used in order to tap levels of delegation cohesion. The first is a standard measure that often has been used. The PARTY VOTING measure is based on the percentage of the time that 50 percent of one party voted against 50 percent of the other party. ${ }^{2}$ As such this measure simultaneously (but imperfectly) captures interparty conflict as well as the degree to which parties cohere. Usually this measure is reported in the aggregate for the Congress. In this analysis, however, the focus is with state delegations. For each state an average Party Voting score was calculated for each party. The score was derived from the percentage of times individual members voted with their party on party votes. Someone who rarely voted with the party majority when the parties were in conflict would have a low score (a score below 50 was quite rare), while someone always backing the party would have a score approaching 100. Consequently, highly partisan delegations had average scores approaching 100 and weakly partisan delegations had lower scores. Figure 1 shows the overall party voting averages, by party and year, for the House. What is apparent is that the overall rates of party voting are high for both parties. They climb during the 1890s and then begin to decline in the second decade of the 20 th century.

\section{<Figure 1 About Here>}

A second measure is borrowed from Poole and Rosenthal (1997). PARTY NOMINATE is a measure of partisan distance calculated from the two-dimensional individual-level scores produced by Keith Poole and Howard Rosenthal from all votes cast in a Congress. Their two dimensions are used to construct a new dimension that yields the best fitting measure of partisanship for the two dominant parties. ${ }^{3}$ Here too state delegation means, derived from member's scores, are calculated for both parties in each Congress. Because of the way in which the Poole and Rosenthal data are normalized, scores close to zero reflect low partisan attachment -- that is such members tend to be as close to one party as the other in their voting behavior. Scores toward a value of 1.0 are extreme Republicans, while scores tending toward -1.0 are extreme Democrats. Figure 2 plots the overall averages for both parties across time. These data show a similar (and smoother) trend to what was captured in figure 1. In the 1890s partisan allegiance, as recovered through roll call votes, increased. This is clear from the widening distance between the two

2 This measure excludes third parties from the analysis. The focus here is with major party conflict.

3 A PROBIT was estimated for an individual's party affiliation as a function of Poole and Rosenthal's DIM1 and DIM2. The resulting coefficients were used to calulate a single, underlying partisan dimension. This is easily done with a simple rotation of the two-dimensional Poole and Rosenthal data by an angle given by the estimated coefficients. See the discussion in Posler and Rhodes (1997). 
parties in this period. By the second decade of the 20th century the party averages move toward zero (and one another), indicating that partisanship was in decline.

$<$ Figure 2 About Here>

The independent variables, by and large, are dummy variables that are turned on when particular voting rules were implemented in the state and turned off otherwise. At the same time, in order to assess the long-term impact of the reform, counter variables are included. Prior to implementing a reform the appropriate counter variable was coded as zero. In the first Congress for which the reform was implemented, the counter was assigned a value of one and then was incremented by a value of one for each subsequent Congress. Consequently, the dummy variable can be thought of as the immediate impact of the reform (an intercept effect) while the counter is the long-term impact of the reform (the slope effect).

The first set of variables focused on balloting procedures that sought to lessen the influence of organized political machines. For example, AUSTRALIAN BALLOT is a variable indicating whether or not the secret ballot was adopted by a state. Because these data are organized by Congress and state delegation, the variable is coded as a zero in those years prior to the adoption of the secret ballot and coded as one when the ballot system was implemented in time for elections to that Congress. ${ }^{4}$ The Australian ballot was implemented under a number of variations by the states. Nonetheless it shared the common feature that balloting would be secret and that the state or local government would print the ballots. Much of the movement for the Australian ballot occurred in the 1890's with most of the states quickly adopting this procedure (see discussions by Rusk, 1970 or Fredman, 1968).

Coupled with the Australian ballot were two additional features of ballot reform. Prior to the introduction of the Australian ballot political parties printed their own slates which served as ballots. This enabled voters to cast their ballot for a straight party ticket. Voting a split ticket usually meant cutting and pasting a new name over a name for a candidate for a particular party. Of course parties and splinter groups within parties often appropriated one another's colors and party symbols such that there was a hodgepodge of ballots. With the introduction of the Australian ballot, fundamental questions were raised

\footnotetext{
4 The dates when states adopted the Australian ballot are widely available. Most recently those dates were published in Katz and Sala (1996) Table 1. With respect to the other variables coded in this study, the dates for implementing new reforms came from a variety of sources. These include U.S. Government documents like Provisions of Election Laws in the Different States (1897), Summary of Statutes and Constitutional Provisions in Force in the Various States, November 1916 (1917); Merriam and Overacker (1928); Harris (1929); and Luddington (1911). These sources were supplemented and double checked using WestLaw Digest for each of the states. WestLaw produces a useful point of reference for a variety of election laws and is usually thorough in presenting the statutes and case law pertaining to elections.
} 
as to whether candidates parties could be listed under a PARTY COLUMN and whether STRAIGHT TICKET voting was allowed. The reform movements pressing the Australian ballot viewed many local political parties as corrupt machines and aimed to eliminate all references to party on ballots. While the Australian ballot was adopted quickly in most states, it took some time for states to allow candidates to be listed under a party column. Even when candidates could be listed in such a manner, many states refused to allow straight ticket voting. The coding rules were relatively straightforward. The PARTY COLUMN dummy variable was switched on when the state allowed candidates to be listed under a party name or party emblem. STRAIGHT TICKET was triggered when states allowed a voter to check a single box to vote for the entire party slate.

A final reform aimed at undermining the grip of party bosses over elections involved the routinization and oversight of primary elections. Many reformers in the late 19th century thought party conventions (when they occurred) to be dominated by political machines that were able to ratify their slates without problem (Mayer, 1902). A primary system was thought to be a way of letting rank and file partisans have the opportunity to nominate the "best" candidates. Moreover, when overseen by state government, a primary was viewed as overcoming corrupt election practices. PRIMARY is a dummy variable indicating when a state adopted a state-wide primary election process. It should be noted that, as with many of these reforms, requiring the state as a whole to use primaries often lagged behind requiring large municipalities implement the reform. As was often the case at the turn of the century, many state legislatures pointed to urban machine politics as the chief source of corrupted elections, while ignoring the fact that the same reforms could be more broadly applied.

A second set of reforms aimed at making it more or less difficult for citizens to vote. The poll tax was directed at blocking black electoral participation in the south. Poll taxes were generally introduced at the turn of the 20th century and involved pre-paying a fee in order to cast a ballot. These fees were not exorbitant, usually in the range of $\$ 1.50$ to $\$ 5.00$ per year. However, the fee was often waived for whites and the time period during which the poll tax could be paid was often only a few days out of the year. POLL TAX then is a dummy variable indicating when a state implemented poll tax laws.

Registration laws had a different aim. While registration requirements were nominally aimed at eliminating individuals from voting more than once, the net effect was to limit access to the polls by the ill-educated working poor. Registration laws required that voters prove they were eligible prior to an election. REGISTRATION is a dummy variable indicating when state-wide voter registration was required. 
The final reforms considered expanded the franchise. Many states adopted legislation providing women the right to vote well prior to the adoption of the 19th Amendment. This obviously had the effect of expanding the franchise to a large population. The dummy variable SEX is coded to reflect when women were granted the right to vote. Finally a movement for absentee voting was also pressed in many of the states. While absentee voting had long been extended to soldiers at war, reformers thought this right should be extended to all citizens. ABSENTEE is coded one when a state adopted absentee voting rules extending to all eligible voters.

Several additional control variables are included in the analysis. First, all estimations are performed separately for the two major parties. This aids considerable in interpretation. Second, a dummy variable for SOUTH is included. This variable takes on a value of one for those states that were part of the Confederacy. As many have shown, in this period the South is different and has an impact on estimations. Third I control the extent of turnover in state delegations. RETURN calculates the proportion of members from the same party in a state that returned to Congress. This captures the continuity of members to the delegation and enables me to estimate whether changes in state delegation averages are a function of replacement of members or due to changes by the members themselves. Finally, the size of the delegation is controlled for in some of the estimations. It is likely that the delegation averages are sensitive to the number of members in a delegation -- in states where there is only a single Democrat or Republican and that member turns over, this can yield considerable volatility in the time series.

\section{Analysis}

All of the analysis reported here is based on OLS. Because this data set is a pooled time series with multiple cross sections there are a number of cautionary provisos that need to be kept in mind. Obviously some set of corrections should be added to the data to correct for serial correlation in the errors, among other problems. These data pose real problems for standard correction techniques. Because the analysis proceeds by estimating the parties separately there are numerous "holes" in the time series in some cross sections. It is simply a fact of life that in some years there were no members of one party elected to Congress in some states.

Not correcting these data and resorting to OLS may not be too devastating a problem. As Beck and Katz (1995) point out, many of the standard corrections are unstable when the ratio of cross sections to time series is large. These data have exactly this problem, with upwards of 48 states in the cross section compared with 29 points in the 
time series for each cross section. They argue that OLS is robust -- certainly with respect to the coefficients -- although the standard errors will be unreliable. Some corrections (using GLM techniques with Parks corrections) were tried over a subset of these data where the series was complete, with no changes in the direction or relative strength of the parameter estimates. As such, the analysis proceeds with OLS, Keeping in mind concerns over the reliability of the standard errors.

Table 1 produces estimates for both the Party Voting and Poole/Rosenthal partisanship measures regressed on the set of ballot reforms that took place primarily in the 1890s. While not estimated in the same fashion as that presented in Reynolds (1997), many of the patterns are consistent with her results. Taking the Party Voting measure first and focusing the intercept term it is clear that there were high levels of party voting irrespective of ballot reform changes. Consistent with Reynolds the introduction of the Australian ballot increased partisanship for both Democrats and Republicans. So too did the introduction of Party Column voting (although there is a great deal of variability). Straight Ticket voting, while strong for Democrats, had no effect for Republicans. In sum, by looking at just the dummy variables, the impact of ballot reforms on party voting was positive and indicates increased partisanship. These findings are reproduced when using the Poole/Rosenthal measure of partisan distance. However, because of the differences in the signs for these variables, it is important to consider the parties separately. The intercept term for the two parties is correctly signed. For the Democrats the introduction of the Australian ballot moves state delegation averages away from the Republicans (hence the negative coefficient), while for Republican the opposite is true. Likewise the effect of Party Column lists is equivalently signed and the effects are roughly the same. For neither party are the effects of Straight Ticket voting very strong.

\section{<Table 1 About Here>}

While these effects may seem strong, support Reynold's findings and are consistent with Hypothesis 2, the counter variables call into question whether these reforms were long lasting. For the Party Voting variable the counters are all negatively signed, pointing out that as time passed from implementing the reform, its effect eroded. For example a state adopting a Party Column ballot in 1894, and showing an increase in Democratic party voting of almost 2.6 percent effectively lost that gain in 20 years (10 Congresses). A similar finding holds when looking at the Poole and Rosenthal partisan distance measure. For Democrats the counters are all positively signed, pointing to an erosion of partisan distance and a movement toward zero. For Republicans the signs are opposite but also moving Republican positions toward zero. 
In sum, the estimates in Table 1 indicate that these early ballot reforms cemented stronger partisan positions. This confirms Reynold's finding and supports Hypothesis 2 . At the same time, these findings point out that the impact of these ballot reforms declined over time. Is this because these reforms had little permanence or was it because other reforms had an intervening effect? If the latter, such a finding supports both Hypothesis 1 and 3.

To answer this question, all of the reforms and their respective counters are estimated. These estimates are given in Table 2. Because Republicans rarely turn up in Southern states and in states imposing a poll tax during this period, those parameters are omitted. Otherwise the estimates are calculated in the same manner as the coefficients in Table 1. What is notable about these estimates is the relative stability of the ballot reform coefficients. Their strength and direction are maintained with the addition of these new variables.

\section{<Table 2 About Here>}

It is clear that the electoral process reform variables have a consistent, negative impact on partisanship. The only exception is the Poll Tax which contributes positively to party cohesion among the 10 southern states that adopted this change at the turn of the century. In part the Poll Tax variable is picking up aspects of Democratic cohesion in the South. ${ }^{5}$ Otherwise, these participation variables quickly swamp the effects of ballot reforms -- both in terms of the dummy variables and the cumulating time series counters. For Democrats and Republicans alike, opening voting to women, constraining participation through registration requirements, allowing for absentee voting and implementing a system of primaries for the nomination of candidates, decreased levels of Party Voting cohesion among state delegations. Each of the coefficients for the dummy variables are negatively signed and so too are the counter variables. This indicates, with respect to Party Voting, that delegation cohesion levels steadily declined. The table also shows that the impact of these reforms was much greater for Republican delegations.

A similar finding holds when looking at the Poole/Rosenthal partisan distance measure. For Democrats the dummy variable coefficients are positively signed, pulling delegations toward zero. For Republicans the coefficients are negative, also pulling state delegations toward zero. In both instances these variables close the gap between the two parties, implying a decrease in partisan attachment and partisan conflict.

\footnotetext{
5 In analysis not reported here, estimates were run including only the 13 states that were members of the Confederacy. There, the Poll Tax variable was not significant for Party Voting and had a weaker, but significant effect on the Poole/Rosenthal party distance measure. Given that 10 of 13 Southern states imposed the Poll Tax, there is a high degree of intercorrelation between that variable and the dummy variable representing the South.
} 
It may be the case that these estimates are largely driven by fluctuating values due to small sized state party delegations. To explore this possibility the equations from Table 2 were re-estimated, including only delegations with three or more members. Table 3 provides these estimates. Clearly, the findings from Table 2 are quite robust. Some minor changes are worth note. First, the effect of the Australian ballot is dampened for Democratic and Republican delegations alike. Second, the impact of Absentee voting is heightened (and leads to a decrease in partisanship). Even so, the basic findings from above are supported -- ballot reforms led to short-term increases in partisan cohesion. However, consistent with hypotheses 1 and 3, reforms tied to participation led to declining partisanship.

\section{<Table 3 About Here>}

In order to clarify the complex relationships between these reforms which occurred at quite different times, Figures 3 and 4 plot the predicted values for Party Voting under a variety of conditions. Figure 3 is for Democrats, while the other is for Republicans. The first line, marked by squares, produces the estimated impact of ballot reforms alone on Party Voting, while including counter variables controlling for the passage of time. The second line, denoted by diamonds, shows the joint effects of ballot reforms and electoral participation reforms, again controlling for variables accounting for time. Finally, the third line, marked by triangles, estimates Party Voting strictly as a function of the passage of time. It is important to keep in mind that the lines are only predicted values, denoted by fixing a variety of reforms at different times. The choices reflected here are fixed by the median time at which the reforms were implemented. The times picked for Ballot reforms are: Australian ballot (1892); Party Column (1896); and Straight Ticket Voting (1900). Reforms linked to participation are given by: Women's Suffrage (1914); Poll Tax (1900); Registration (1898); Absentee Voting (1914); and Primaries (1906).

$<$ Figures 3 and 4 About Here>

Figure 3 points to levels of Democratic Party voting. In this figure, only nonSouthern states are considered (for southern states the level of party voting would increase by approximately 12 points). The overall time trend is practically zero, although increasing slightly. Ballot reforms alone, as noted above, are correlated with increasing levels of Party Voting. The entire series of reforms, ranging from the Australian ballot to Straight Party Voting, leads to an increase in levels of Party Voting. However, as can be see from the dips in Party Voting, the compounded effect of time results in a steady decline. When participatory reforms are put into place there is a similar trend. Peaking around 1898, there is a steady decline in Party Voting. There is an especially pronounced drop around 1914, which is a function of the Women's Suffrage and Absentee Voting effects. No matter how 
these reforms are dissected, following a brief upturn in Party Voting, there is a steady, compounded decline following the major ballot reforms.

A similar finding holds for Republicans. Figure 4 points to a steady decline in Party Voting over time when controlling for nothing else. Ballot reforms lead to a short upturn in Party Voting, with a subsequent decline by 1898. By comparison with Democrats, the short term increase from the Ballot reforms for Party Voting is smaller, while the overall decrease is the same.

In general these findings support all three hypotheses and not their alternatives. Reynold's prediction, contained in Hypothesis 2, is confirmed. The short term effect of Ballot reform was to strengthen partisan attachment in Congress. At the same time, Hypothesis 3 is borne out. The longer term effect of a variety of electoral reforms was associated with a decline in partisanship. Finally, the principal hypothesis for this research is supported. The net effect of electoral reforms in the late 19th and early 20th century was strongly associated with a decline in partisanship.

\section{Conclusion}

In a sense both the received wisdom and its current challenge are both correct. A decline in partisanship did indeed occur contemporaneous with a large number of reforms to the U.S. electoral system. On the other hand there was an increase in partisanship prior to the general decay. That increase was most closely associated with one sort of electoral reform: balloting.

Because electoral reforms were implemented at different times in different states, econometric techniques ought to be able to test whether specific reforms had any impact. The findings here clearly show that both ballot and participatory reforms had differential effects -- even though they were widely dispersed through time. This leads to the tentative conclusion that Reynolds has part of the story correct. Ballot reforms, which targeted local political machines, strengthened the upper hand of state and national party leaders. By centralizing the voting process partisan brokers exacted greater allegiance by party members in Congress. However, reforms that affected who could participate had exactly the opposite effect. Such reforms, while constraining some (notably blacks and the lower classes) opened the process to others (notably women). The net impact of these reforms, coupled with the lingering effects of Ballot reforms, was to undermine the linkage between party leaders and partisans in Congress. In this sense the standard story as told by Burnham (among others) is probably correct as well. Progressive reforms implemented during the first two decades of the 20th century hurried a decline in partisanship in Congress. Ballot reforms were insufficient to bring about the changes that were observed, 
in fact, they initially contributed toward increasing levels of partisanship as state and national leaders reasserted their prominence in the U.S. Congress.

The electoral reforms noted here are very blunt instruments. The reader ought to be skeptical that these reforms alone resulted in the changes noted above. As Rohde (1992) notes, in order to get a complete picture of shifting levels of partisanship, it is important to understand the context. "Conditional party government" depends importantly on the issues that come before a legislature. Those issues are pressed by both leadership and by national needs. The same point was raised long ago and extensively discussed by Cooper, Brady and Hurley (1977). Clearly the period leading up to 1896 was nothing less than a battle for the soul of the nation. As all political historians have noted, the 1896 election clearly defined the Republican party and carried it into the 20th century, while the Democratic party collapsed about itself. Such a national election could not help but have an effect on partisan attachment in Congress. Carefully disentangling what was due to the political agenda presented by partisan leaders and what was due to member's responses to new electoral incentives remains unanalyzed. However, such analysis is needed before we can speak confidently of the overall impact of reforms in the Age of Reform. 
Bibliography

Brady, David W., Joseph Cooper and Patricia A. Hurley. 1979. "The Decline of Party in the U.S. House of Representatives, 1887-1968." Legislative Studies Quarterly 4: 381-407.

Burnham, Walter Dean. 1970. Critical Elections and the Mainsprings of American Politics. New York: W. W. Norton and Company.

Cooper, Joseph, David W. Brady and Patricia A. Hurley. 1977. "The Electoral Basis of Party Voting: Patterns and Trends in the U.S. House of Representatives, 18871969." In Louis Maisel and Joseph Cooper (eds.) The Impact of the Electoral Process. Beverly Hills: Sage Publications.

Fredman, L. E. 1968. The Australian Ballot: The Story of an American Reform. East Lansing: Michigan State University Press.

Galderisi, Peter F. and Benjamin Ginsberg. 1986. "Primary Elections and the Evanescence of Third Party Activity in the United States." In Do Elections Matter? Benjamin Ginsberg and Alan Stone (eds.). Armonk, New York: M. E. Sharpe, Inc., pp. 115-130.

Harris, Joseph P. 1929. Registration of Voters in the United States. Washington, D.C.: The Brookings Institution.

Hurley, Patricia A. and Rick K. Wilson. 1988. "Partisan Voting Patterns in the U.S. Senate, 1877-1986." Legislative Studies Quarterly 14: 225-250.

Lijphart, Arend. 1994. Electoral Systems and Party Systems. New York: Oxford University Press.

Luddington, Arthur C. 1911. American Ballot Laws, 1888-1910. Albany, NY: University of the State of New York.

Mayer, Ernst C. 1902. Nominating Systems: Direct Primaries versus Conventions in the United States. Madison, WI: Published by Author.

Merriam, Charles E. and Louise Overacker. 1928. Primary Elections.

Patterson, Samuel C. and Gregory A. Calderia 1988 "Party Voting in the United States Congress." British Journal of Political Science 18: 111-131.

Poole, Keith T. and Howard Rosenthal. 1997. Congress : a political-economic history of roll call voting. New York: Oxford University Press

Posler and Rhodes (1997) -- LSQ paper

Reynolds, Lisa A. 1995. "Reassessing the Impact of Progressive Era Ballot Reform," (Ph.D. dissertation, University of California, San Diego).

Reynolds, Lisa A. 1997. "The Australian Ballot and Party Voting: Re-examining the electoral origins of 20th century party decline." Unpublished manuscript, Arizona State University. 
Rohde, David W. 1991. Parties and Leaders in the Postreform House. Chicago: University of Chicago Press.

Rohde, David W. 1992. "Agenda Change and Partisan Resurgence in the House of Representatives." In Alan D. Hertzke and Ronald M. Peters (eds.) The Atomistic Congress. Armonk, NY: M.E. Sharpe, pp. 231-258.

Rusk, Jerrold G. 1970. "The Effect of the Australian Ballot Reform on Split Ticket Voting, 1876-1908.” American Political Science Review. 64: 1220-1236.

Rusk, Jerrold G. and John J. Stucker. 1978. "The Effect of the Southern System of Election Laws on Voting Participation: A Reply to V.O. Key." In The History of American Electoral Behavior. Joel H. Silbey, Allan G. Bogue and William H. Flanigan (eds.). Princeton: Princeton University Press, pp. 198-250.

Senate, United States Congress. 1897. Provisions of Election Laws in the Different States. 54th Congress, 2nd Session (Document 91). Washington: US Government Printing Office.

Senate, United States Congress. 1917. Summary of Statutes and Constitutional Provisions in Force in the Various States, November 1916 . 64th Congress, 2nd Session. (Document 659). Washington: US Government Printing Office.

Shugart, Matthew S. and John M. Carey. 1992. Presidents and assemblies : constitutional design and electoral dynamics. Cambridge: Cambridge University Press.

Taagepera, Rein and Matthew S. Shugart. 1989. Seats and votes : the effects and determinants of electoral systems. New Haven : Yale University Press

Weibe, Robert H. 1967. The Search for Order, 1877-1920. New York: Hill and Wang.

WestLaw 
Table 1.

Ballot Reforms Only (Standard Errors in Parentheses)

\begin{tabular}{|c|c|c|c|c|}
\hline & $\begin{array}{l}\text { Party Voting } \\
\text { Democrats } \\
\end{array}$ & Republicans & $\begin{array}{l}\text { Poole } \\
\text { Rosenthal } \\
\text { Democrats } \\
\end{array}$ & Republicans \\
\hline Intercept & $\begin{array}{c}75.409 * * \\
(.70)\end{array}$ & $\begin{array}{l}87.208 * * \\
(.558)\end{array}$ & $\begin{array}{c}-.285 * * \\
(.008)\end{array}$ & $\begin{array}{l}.417 * * \\
(.007)\end{array}$ \\
\hline $\begin{array}{l}\text { Australian } \\
\text { Ballot }\end{array}$ & $\begin{array}{c}3.456^{* *} \\
(1.113)\end{array}$ & $\begin{array}{l}2.525 * \\
(1.043)\end{array}$ & $\begin{array}{l}-.030 * \\
(.012)\end{array}$ & $\begin{array}{l}.090 * * \\
(.013)\end{array}$ \\
\hline $\begin{array}{l}\text { Australian } \\
\qquad \begin{array}{l}\text { Ballot } \\
\text { Counter }\end{array}\end{array}$ & $\begin{array}{l}-.170 \\
(.086)\end{array}$ & $\begin{array}{c}-.218 * * \\
(.083)\end{array}$ & $\begin{array}{l}.007 * * \\
(.001)\end{array}$ & $\begin{array}{c}-.009 * * \\
(.001)\end{array}$ \\
\hline Party Column & $\begin{array}{c}2.594 \\
(1.389)\end{array}$ & $\begin{array}{c}2.370 \\
(1.244)\end{array}$ & $\begin{array}{l}-.033 * \\
(.015)\end{array}$ & $\begin{array}{l}.070 * * \\
(.016)\end{array}$ \\
\hline $\begin{array}{l}\text { Party Column } \\
\text { Counter }\end{array}$ & $\begin{array}{l}-.245^{*} \\
(.118)\end{array}$ & $\begin{array}{l}-.206 \\
(.116)\end{array}$ & $\begin{array}{l}.002 \\
(.001)\end{array}$ & $\begin{array}{c}-.005 * * \\
(.002)\end{array}$ \\
\hline Straight Ticket & $\begin{array}{l}3.836^{*} \\
(1.516)\end{array}$ & $\begin{array}{c}-.677 \\
(1.270)\end{array}$ & $\begin{array}{l}-.017 \\
(.016)\end{array}$ & $\begin{array}{l}-.012 \\
(.017)\end{array}$ \\
\hline $\begin{array}{l}\text { Straight Ticket } \\
\text { Counter }\end{array}$ & $\begin{array}{l}-.222 \\
(.147)\end{array}$ & $\begin{array}{l}-.131 \\
(.124)\end{array}$ & $\begin{array}{l}.0004 \\
(.002)\end{array}$ & $\begin{array}{l}.001 \\
(.001)\end{array}$ \\
\hline South & $\begin{array}{c}12.591 * * \\
(.717)\end{array}$ & -- & $\begin{array}{c}-.166 * * \\
(.008)\end{array}$ & -- \\
\hline & $\mathrm{n}=893 \mathrm{r}^{2}=.29$ & $\mathrm{n}=948 \mathrm{r}^{2}=.06$ & $\mathrm{n}=900 \mathrm{r}^{2}=.43$ & $\mathrm{n}=955 \mathrm{r}^{2}=.19$ \\
\hline
\end{tabular}


Table 2.

All Electoral Reforms (Standard Errors in Parentheses)

\begin{tabular}{|c|c|c|c|c|}
\hline & $\begin{array}{l}\text { Party Voting } \\
\text { Democrats }\end{array}$ & Republicans & $\begin{array}{l}\text { Poole } \\
\text { Rosenthal } \\
\text { Democrats } \\
\end{array}$ & Republicans \\
\hline Intercept & $\begin{array}{c}77.296 * * \\
(.854)\end{array}$ & $\begin{array}{c}87.644 * * \\
(.687)\end{array}$ & $\begin{array}{c}-.300^{* *} \\
(.009)\end{array}$ & $\begin{array}{c}.399 * * \\
(.009)\end{array}$ \\
\hline Australian Ballot & $\begin{array}{c}4.244 * * \\
(1.103)\end{array}$ & $\begin{array}{l}1.342 \\
(.961)\end{array}$ & $\begin{array}{c}-.034 * * \\
(.012)\end{array}$ & $\begin{array}{l}.090 * * \\
(.013)\end{array}$ \\
\hline $\begin{array}{c}\text { Australian Ballot } \\
\text { Counter }\end{array}$ & $\begin{array}{l}-.005 \\
(.105)\end{array}$ & $\begin{array}{l}.145 \\
(.099)\end{array}$ & $\begin{array}{l}.002 \\
(.001)\end{array}$ & $\begin{array}{c}-.004 * * \\
(.001)\end{array}$ \\
\hline Party Column & $\begin{array}{c}2.056 \\
(1.363)\end{array}$ & $\begin{array}{l}2.845 * \\
(1.159)\end{array}$ & $\begin{array}{l}-.013 * \\
(.014)\end{array}$ & $\begin{array}{l}.057 * * \\
(.016)\end{array}$ \\
\hline $\begin{array}{l}\text { Party Column } \\
\text { Counter }\end{array}$ & $\begin{array}{l}-.160 \\
(.126)\end{array}$ & $\begin{array}{l}-.229 * \\
(.114)\end{array}$ & $\begin{array}{l}-.000 \\
(.001)\end{array}$ & $\begin{array}{c}-.005 * * \\
(.002)\end{array}$ \\
\hline Straight Ticket & $\begin{array}{l}3.909 * \\
(1.565)\end{array}$ & $\begin{array}{c}-.879 \\
(1.228)\end{array}$ & $\begin{array}{c}-.046 * * \\
(.016)\end{array}$ & $\begin{array}{c}.003 \\
(.017)\end{array}$ \\
\hline $\begin{array}{r}\text { Straight Ticket } \\
\text { Counter }\end{array}$ & $\begin{array}{l}-.208 \\
(.160)\end{array}$ & $\begin{array}{l}-.078 \\
(.121)\end{array}$ & $\begin{array}{l}.003 \\
(.002)\end{array}$ & $\begin{array}{l}-.000 \\
(.002)\end{array}$ \\
\hline Women's Vote & $\begin{array}{c}-4.459 * * \\
(.854)\end{array}$ & $\begin{array}{c}-3.087 * * \\
(1.039)\end{array}$ & $\begin{array}{l}.057 * * \\
(.013)\end{array}$ & $\begin{array}{c}-.063 * * \\
(.014)\end{array}$ \\
\hline $\begin{array}{r}\text { Women's Vote } \\
\text { Counter }\end{array}$ & $\begin{array}{l}.294 \\
(.175)\end{array}$ & $\begin{array}{l}.185 \\
(.121)\end{array}$ & $\begin{array}{l}-.001 \\
(.002)\end{array}$ & $\begin{array}{l}.004 * \\
(.002)\end{array}$ \\
\hline Poll Tax & $\begin{array}{c}1.153 \\
(1.682)\end{array}$ & - & $\begin{array}{c}-.060 * * \\
(.018)\end{array}$ & - \\
\hline Poll Tax Counter & $\begin{array}{l}-.022 \\
(.147)\end{array}$ & - & $\begin{array}{l}.009 * * \\
(.002)\end{array}$ & - \\
\hline Registration & $\begin{array}{l}-1.347 \\
(.994)\end{array}$ & $\begin{array}{l}.272 \\
(.803)\end{array}$ & $\begin{array}{l}.013 \\
(.010)\end{array}$ & $\begin{array}{l}-.007 \\
(.011)\end{array}$ \\
\hline $\begin{array}{l}\text { Registration } \\
\text { Counter }\end{array}$ & $\begin{array}{l}-.118 \\
(.082)\end{array}$ & $\begin{array}{c}.063 \\
(.066)\end{array}$ & $\begin{array}{l}-.0004 \\
(.0009)\end{array}$ & $\begin{array}{c}.002 * \\
(.0009)\end{array}$ \\
\hline Absentee Voting & $\begin{array}{l}-1.878 \\
(1.242)\end{array}$ & $\begin{array}{c}-2.755^{* *} \\
(.993)\end{array}$ & $\begin{array}{c}.025 \\
(.013)\end{array}$ & $\begin{array}{l}-.032 * \\
(.014)\end{array}$ \\
\hline $\begin{array}{c}\text { Absentee Voting } \\
\text { Counter }\end{array}$ & $\begin{array}{c}-.001 \\
(.134)\end{array}$ & $\begin{array}{l}.240 * \\
(.010)\end{array}$ & $\begin{array}{l}-.002 \\
(.001)\end{array}$ & $\begin{array}{l}.004 * * \\
(.001)\end{array}$ \\
\hline Primaries & $\begin{array}{c}-.306 \\
(1.134)\end{array}$ & $\begin{array}{c}-3.300 * * \\
(.953)\end{array}$ & $\begin{array}{l}.039 * * \\
(.012)\end{array}$ & $\begin{array}{c}-.077 * * \\
(.013)\end{array}$ \\
\hline Primaries Counter & $\begin{array}{l}.132 \\
(.144)\end{array}$ & $\begin{array}{l}-.217 \\
(.128)\end{array}$ & $\begin{array}{l}.0002 \\
(.002)\end{array}$ & $\begin{array}{c}-.0004 \\
(.002)\end{array}$ \\
\hline $\begin{array}{l}\text { Returning } \\
\text { Members }\end{array}$ & $\begin{array}{c}-1.472 \\
(.954)\end{array}$ & $\begin{array}{l}.396 \\
(.810)\end{array}$ & $\begin{array}{l}.023 * \\
(.010)\end{array}$ & $\begin{array}{l}.043 * * \\
(.011)\end{array}$ \\
\hline \multirow[t]{2}{*}{ South } & $\begin{array}{l}11.858 * * \\
(.872)\end{array}$ & - & $\begin{array}{c}-.183 * * \\
(.009)\end{array}$ & - \\
\hline & $\mathrm{n}=892 \mathrm{r}^{2}=.32$ & $\mathrm{n}=946 \mathrm{r}^{2}=.13$ & $\mathrm{n}=900 \mathrm{r}^{2}=.52$ & $\mathrm{n}=955 \mathrm{r}^{2}=.27$ \\
\hline
\end{tabular}

$* * p<.01$

$* \mathrm{p}<.05$ 
Table 3.

OLS Estimates of All Reforms for Large State Delegations

(Standard Errors in Parentheses)

\begin{tabular}{|c|c|c|c|c|}
\hline & $\begin{array}{c}\text { Party Voting } \\
\text { Democrats }\end{array}$ & Republicans & $\begin{array}{c}\text { Poole } \\
\text { Rosenthal } \\
\text { Democrats }\end{array}$ & Republicans \\
\hline Intercept & $\begin{array}{c}76.865 * * \\
(.904)\end{array}$ & $\begin{array}{c}88.600 * * \\
(1.026)\end{array}$ & $\begin{array}{c}-.300 * * \\
(.010)\end{array}$ & $\begin{array}{l}.421 * * \\
(.012)\end{array}$ \\
\hline Australian Ballot & $\begin{array}{c}1.737 \\
(1.123)\end{array}$ & $\begin{array}{c}1.957 \\
(1.338)\end{array}$ & $\begin{array}{l}-.011 \\
(.012)\end{array}$ & $\begin{array}{l}.119 * * \\
(.016)\end{array}$ \\
\hline $\begin{array}{c}\text { Australian Ballot } \\
\text { Counter }\end{array}$ & $\begin{array}{l}-.067 \\
(.111)\end{array}$ & $\begin{array}{l}-.248 \\
(.142)\end{array}$ & $\begin{array}{l}.001 \\
(.001)\end{array}$ & $\begin{array}{c}-.011 * * \\
(.002)\end{array}$ \\
\hline Party Column & $\begin{array}{l}3.390 * \\
(1.520)\end{array}$ & $\begin{array}{c}1.936 \\
(1.448)\end{array}$ & $\begin{array}{c}-.042 * * \\
(.016)\end{array}$ & $\begin{array}{l}.046 * * \\
(.018)\end{array}$ \\
\hline $\begin{array}{r}\text { Party Column } \\
\text { Counter }\end{array}$ & $\begin{array}{l}-.308 * \\
(.125)\end{array}$ & $\begin{array}{l}-.129 \\
(.135)\end{array}$ & $\begin{array}{l}.003 \\
(.001)\end{array}$ & $\begin{array}{l}-.003 \\
(.002)\end{array}$ \\
\hline Straight Ticket & $\begin{array}{c}3.246 \\
(1.703)\end{array}$ & $\begin{array}{c}-.425 \\
(1.519)\end{array}$ & $\begin{array}{l}-.025 \\
(.018)\end{array}$ & $\begin{array}{l}-.020 \\
(.018)\end{array}$ \\
\hline $\begin{array}{r}\text { Straight Ticket } \\
\text { Counter }\end{array}$ & $\begin{array}{l}-.024 \\
(.158)\end{array}$ & $\begin{array}{l}-.248 \\
(.143)\end{array}$ & $\begin{array}{l}.001 \\
(.002)\end{array}$ & $\begin{array}{l}-.002 \\
(.002)\end{array}$ \\
\hline Women's Vote & $\begin{array}{c}-5.327 * * \\
(1.361)\end{array}$ & $\begin{array}{l}-2.481 \\
(1.369)\end{array}$ & $\begin{array}{l}.055^{* *} \\
(.015)\end{array}$ & $\begin{array}{c}-.057 * * \\
(.017)\end{array}$ \\
\hline $\begin{array}{r}\text { Women's Vote } \\
\text { Counter }\end{array}$ & $\begin{array}{l}.687 * * \\
(.223)\end{array}$ & $\begin{array}{l}.369 \\
(.199)\end{array}$ & $\begin{array}{l}-.003 \\
(.002)\end{array}$ & $\begin{array}{c}.008 * * \\
(.002)\end{array}$ \\
\hline Poll Tax & $\begin{array}{c}2.178 \\
(1.445)\end{array}$ & - & $\begin{array}{c}-.066 * * \\
(.016)\end{array}$ & - \\
\hline Poll Tax Counter & $\begin{array}{l}-.111 \\
(.127)\end{array}$ & - & $\begin{array}{l}.009 * * \\
(.001)\end{array}$ & - \\
\hline Registration & $\begin{array}{l}-.291 \\
(.966)\end{array}$ & $\begin{array}{c}.841 \\
(1.025)\end{array}$ & $\begin{array}{l}.005 \\
(.010)\end{array}$ & $\begin{array}{l}-.014 \\
(.012)\end{array}$ \\
\hline $\begin{array}{l}\text { Registration } \\
\text { Counter }\end{array}$ & $\begin{array}{l}-.112 \\
(.079)\end{array}$ & $\begin{array}{c}-.0003 \\
(.076)\end{array}$ & $\begin{array}{l}-.0004 \\
(.0009)\end{array}$ & $\begin{array}{l}.001 \\
(.001)\end{array}$ \\
\hline Absentee Voting & $\begin{array}{l}-2.989 * \\
(1.284)\end{array}$ & $\begin{array}{l}-3.065^{*} \\
(1.203)\end{array}$ & $\begin{array}{l}.047 * * \\
(.014)\end{array}$ & $\begin{array}{l}-.027 \\
(.015)\end{array}$ \\
\hline $\begin{array}{c}\text { Absentee Voting } \\
\text { Counter }\end{array}$ & $\begin{array}{l}.178 \\
(.133)\end{array}$ & $\begin{array}{l}.258^{*} \\
(.113)\end{array}$ & $\begin{array}{c}-.004 * * \\
(.001)\end{array}$ & $\begin{array}{l}.004 * * \\
(.001)\end{array}$ \\
\hline Primaries & $\begin{array}{c}1.257 \\
(1.108)\end{array}$ & $\begin{array}{l}-2.830^{*} \\
(1.220)\end{array}$ & $\begin{array}{l}.016 \\
(.012)\end{array}$ & $\begin{array}{c}-.056 * * \\
(.015)\end{array}$ \\
\hline Primaries Counter & $\begin{array}{l}.101 \\
(.134)\end{array}$ & $\begin{array}{l}.155 \\
(.158)\end{array}$ & $\begin{array}{l}.002 \\
(.001)\end{array}$ & $\begin{array}{c}.004 \\
(.002)\end{array}$ \\
\hline $\begin{array}{l}\text { Returning } \\
\text { Members }\end{array}$ & $\begin{array}{c}.637 \\
(1.191)\end{array}$ & $\begin{array}{c}1.399 \\
(1.310)\end{array}$ & $\begin{array}{l}.006 \\
(.013)\end{array}$ & $\begin{array}{l}.063 * * \\
(.015)\end{array}$ \\
\hline \multirow[t]{2}{*}{ South } & $\begin{array}{l}11.099 * * \\
(.808)\end{array}$ & - & $\begin{array}{c}-.171 * * \\
(.009)\end{array}$ & - \\
\hline & $\mathrm{n}=629 \mathrm{r}^{2}=.42$ & $\mathrm{n}=560 \mathrm{r}^{2}=.19$ & $\mathrm{n}=629 \mathrm{r}^{2}=.63$ & $\mathrm{n}=560 \mathrm{r}^{2}=.43$ \\
\hline
\end{tabular}

$* * \mathrm{p}<.01$

$* \mathrm{p}<.05$ 


\section{Figure 1}

\section{Party Voting Scores Over Time By Congress}

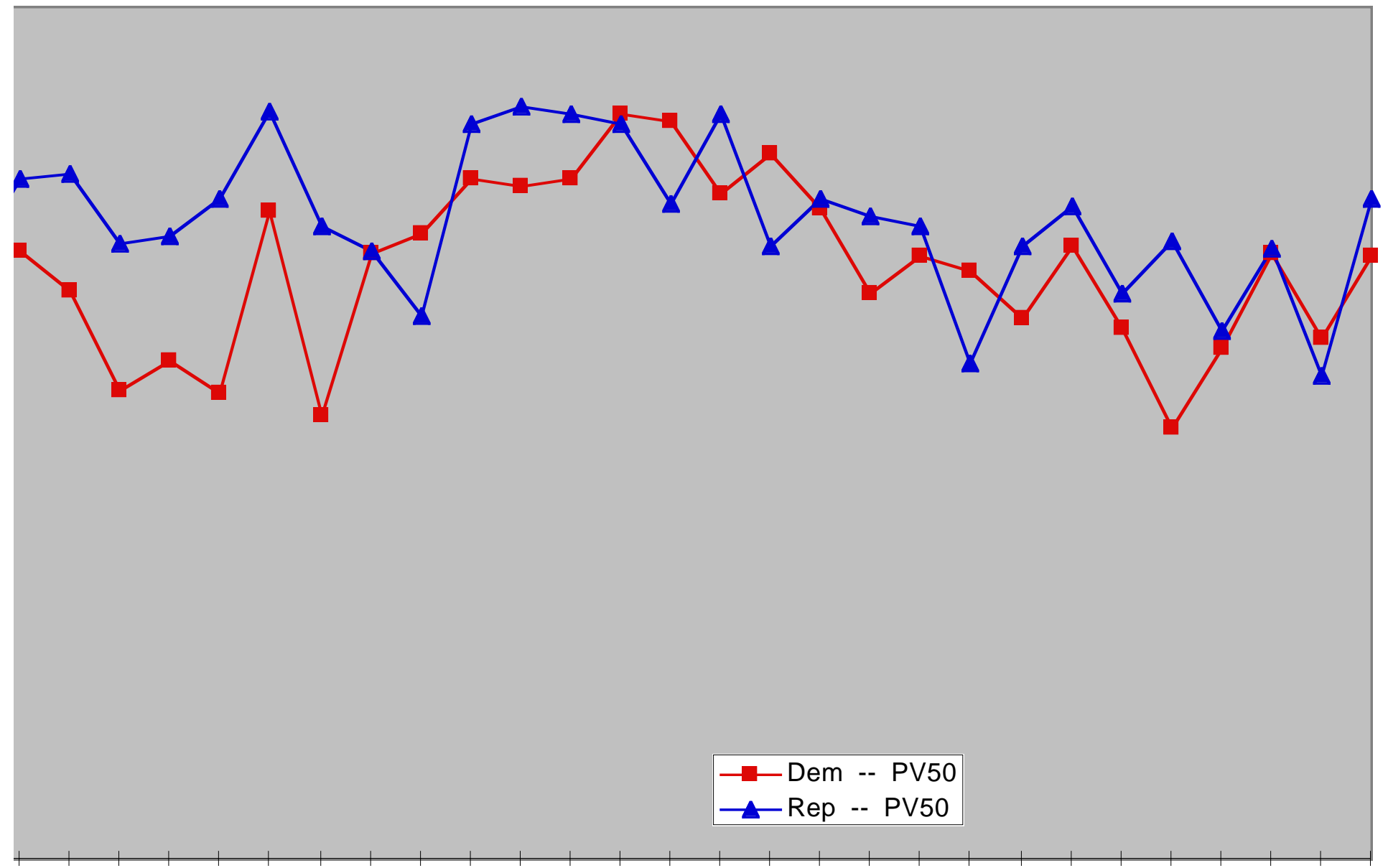

6474849505152535455565758596061626364656667686970717273 Congress 


\section{Figure 2 \\ Party Distance By Congress}

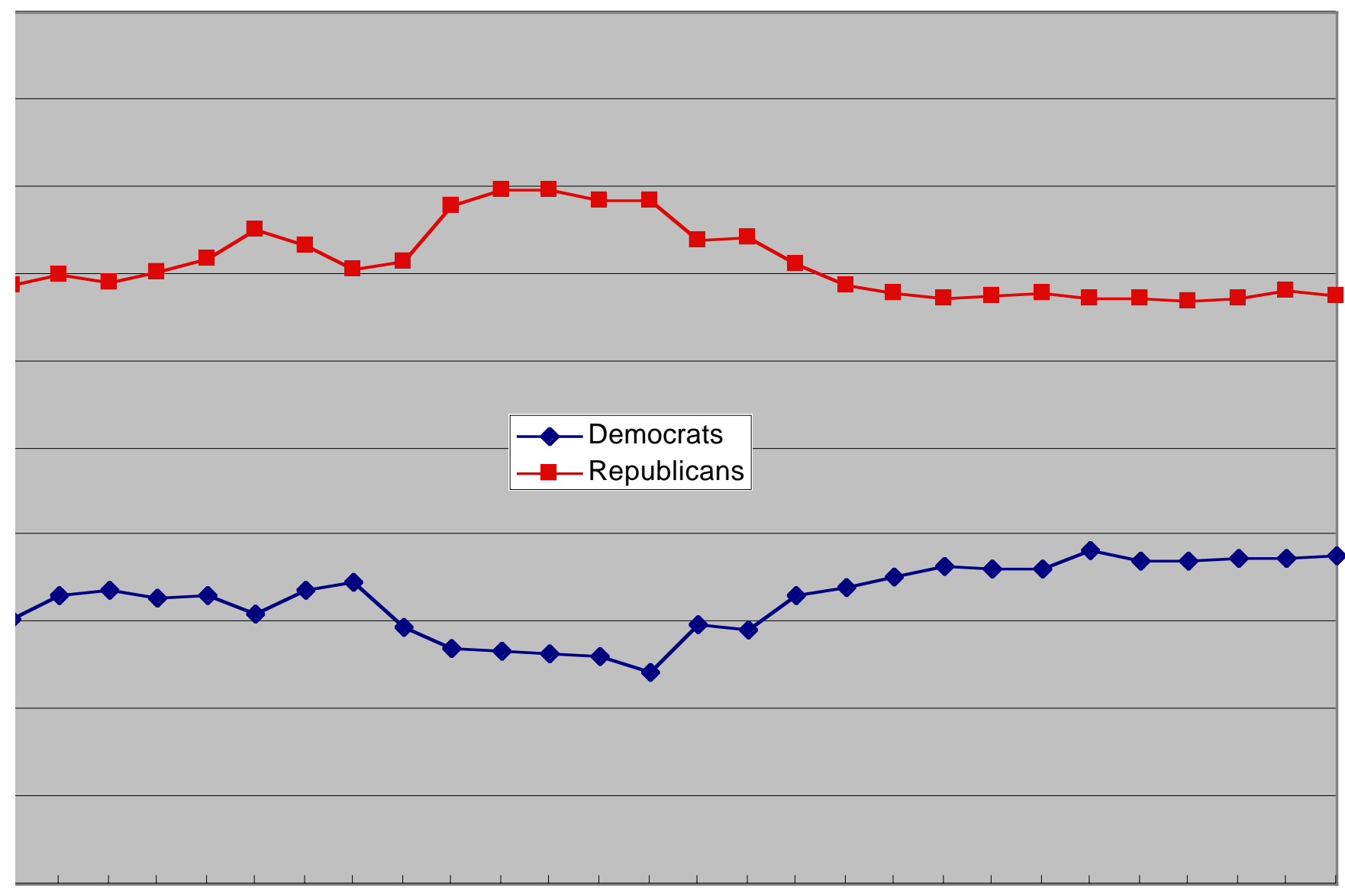

6474849505152535455565758596061626364656667686970717273 Congress 
Figure 3

\section{Predicted Values Based on OLS Estimates -- Democrats}

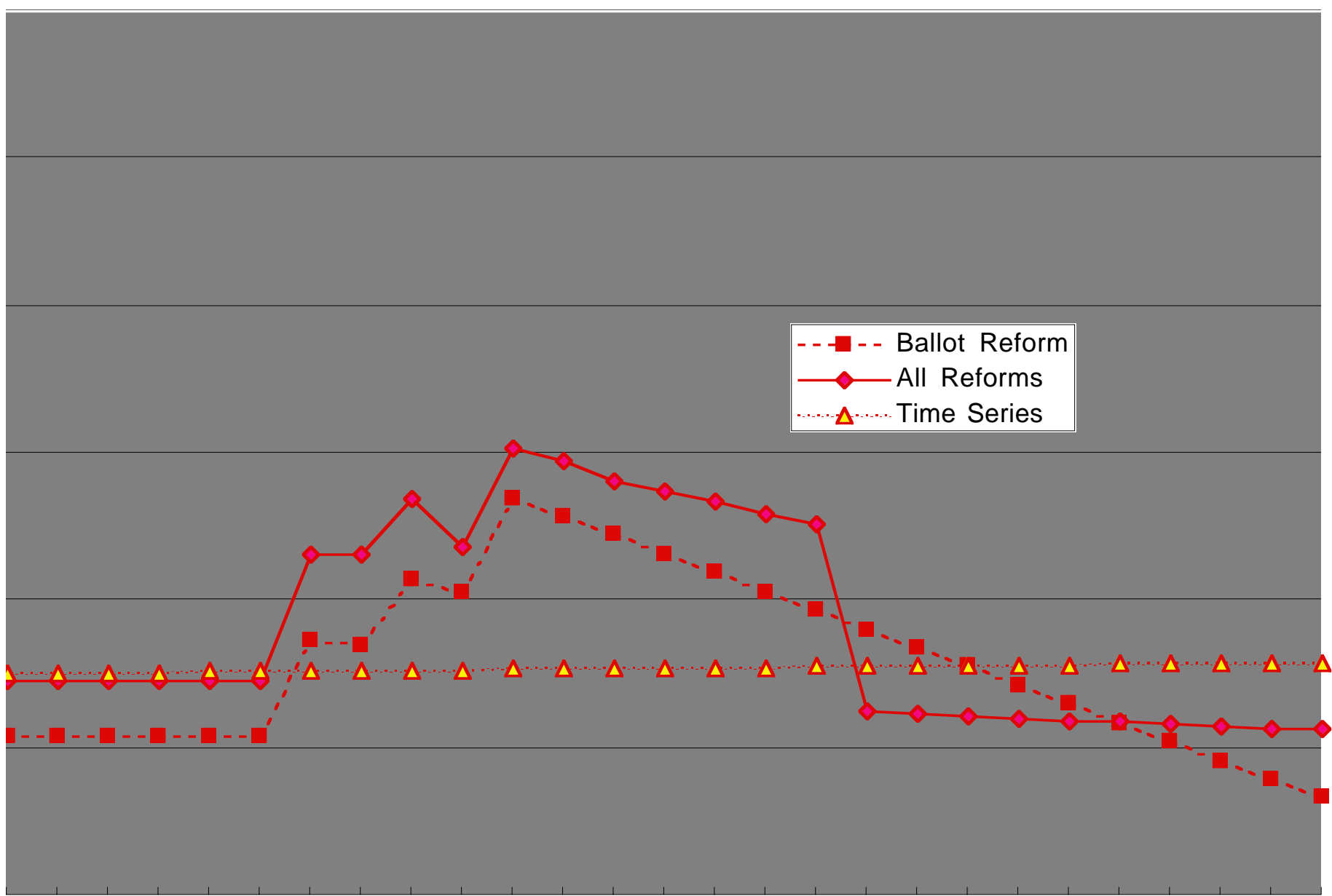

74849505152535455565758596061626364656667686970717273 Congress 
Figure 4

\section{Predicted Values Based on OLS -- Republicans}

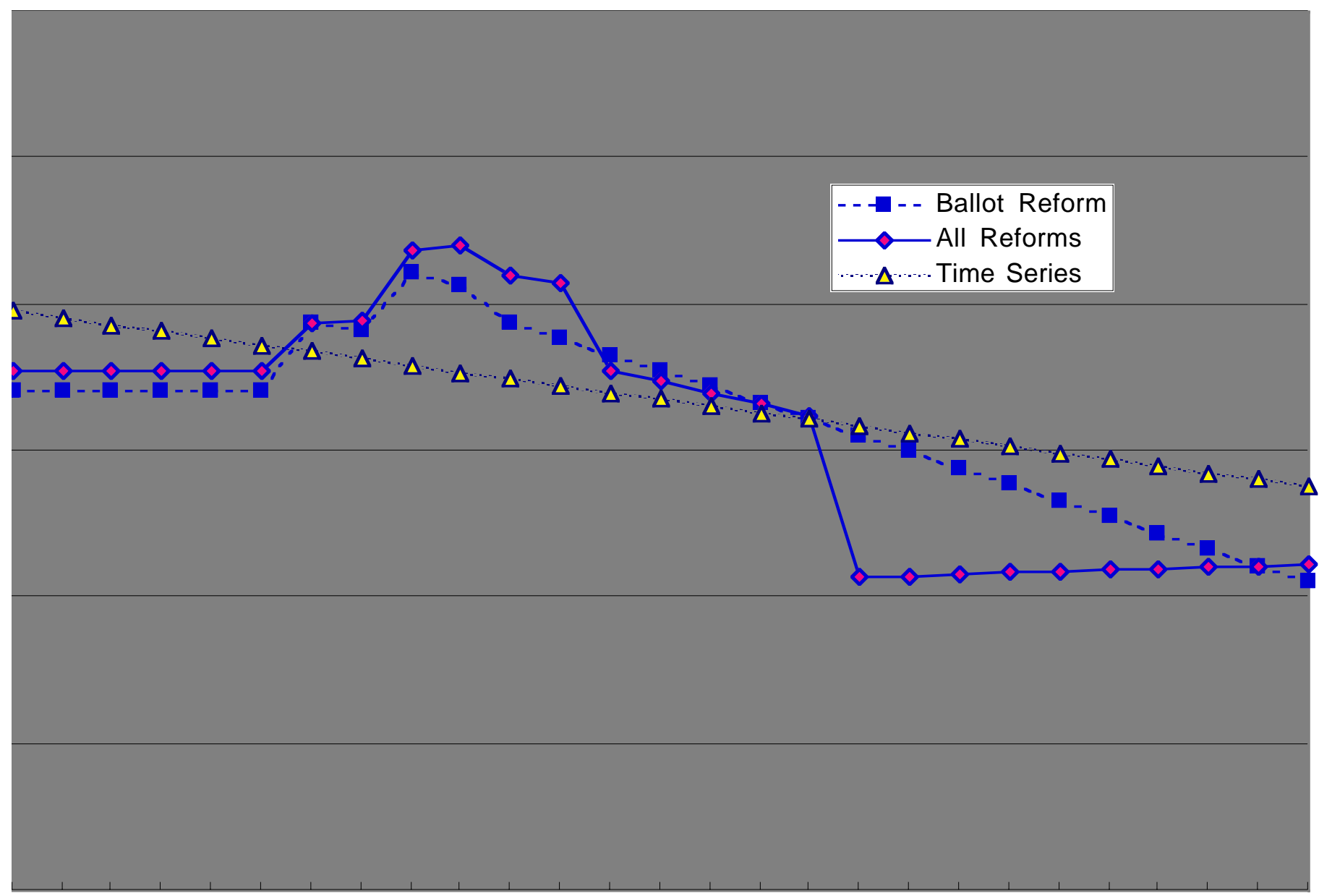

74849505152535455565758596061626364656667686970717273 Congress 